\title{
Democratic Development and Civil Wars: A Quantitative Approach ${ }^{1}$
}

\author{
Qi Jing \\ Ursula Hall, Australian National University, 50 Daley Rd, Acton, ACT 2601 \\ U5782990@anu.edu.au
}

Keywords: Democratic development, civil wars, quantitative method

Abstract: democratic development affects the occurrence of civil wars, countries with intermediate democratic development are more likely to experience civil wars than those with strong democratic or strong autocratic regimes

\section{Introduction}

The theory of democratic peace suggests that the spread of democracy decreases the probability of having 'interstate warfare' (Doyle 1986). However, this theory does not explore whether democratic development also lowers the occurrence of civil wars. Civil wars threaten security and order at both the state and international levels, which merits attention and concerns two elements I find most interesting: institutions and war. I therefore chose the 'frequency of civil wars in authoritarian and democratic regimes' as research topic. The question I have chosen to explore is 'Why is the prevalence of civil war higher in some countries and lower in others?' According to this question, I propose a causal theory that 'democratic development affects the occurrence of civil wars, countries with intermediate democratic development are more likely to experience civil wars than those with strong democratic or strong autocratic regimes', given restrictive definitions of three different levels of democratic development. To test and falsify the theory, a null hypothesis is initialed that 'the probability of having civil wars in countries with semi-democratic regimes are equal in those with strong democratic or strong autocratic regimes'. This paper is merely a primary presentation of my research. It contains three sections. (1) Detailed data selection and research design. (2) Presentation of findings and interpretations of the research. (3) Implications of the findings, falsifications of the research, and advices for future research.

\section{Research Design and Data}

To design a valid research strategy, internal and external validity should be considered (Kellstedt and Guy 2013). Restrictive definitions of different political regimes have been given in relative data codebooks (Marshall and Keith 2016). Following are my research design and data collection.

Research Question. Why is the prevalence of civil war higher in some countries and lower in others?

Hypotheses. Null Hypothesis: The probability of having civil wars in countries with semi-democratic regimes are equal in those with strong democratic or strong autocratic regimes. Alternative Hypothesis: The probability of having civil wars in countries with semi-democratic regimes are higher than in those with strong democratic or strong autocratic regimes.

Data and Variables. All data were accessed from the following web link: http://www.systemicpeace.org/inscrdata.html (Marshall and Keith 2016). The following two datasets have been merged for the analysis: a. Major Episodes of Political Violence, 1946-2015 (MEPV2012ex.csv). b. Polity IV Annual Time-Series, 1800-2015 (p4v2015.csv). To merge the two datasets above, I save them as .csv files. Dataset $p 4 v 2015 . c s v$ had a variable called 'cyear' which is

\footnotetext{
1 Word Count: 1099
} 
Country Year: a unique identifier for each country year, consisting of the country code, CCODE, followed by the year. To create the variable 'cyear' in MEPV2012ex.csv dataset, the following MS Excel formula was used:

= CONCATENATE $(\mathrm{B} 2, \mathrm{D} 2)$.

Finally, each data was imported into Stata and saved as Stata data then merged using the unique key 'cyear'. Independent Variable: polity3 is a categorical variable indicating the type of regime (autocratic, semi-democratic, or democratic). An autocratic regime is a polity with a score in the range -10 to -6 on the democracy-autocracy index. A democratic regime is a polity within the $6-10$ interval. A semi-democratic regime has a score in the range -5 to 5 . While durable is the time (in years) variable which counts the number of consecutive years that a regime is coded with the particular regime type. Dependent Variable: the dependent variable civtot1 is a binary variable indicating the onset of civil war. The variable is coded one for each onset and zero otherwise.

Analysis Method. To test the hypothesis, the following statistical analyses were performed using Stata software: 1. Chi-Square test for Independence. 2. Survival Analysis. This involved obtaining Kaplan-Meier survivor curves and the corresponding harzard rate ratios.

\section{Findings and Interpretations}

Table 1: Results from Chi-Square test for Independence

\begin{tabular}{|c|}
\hline Key \\
\hline fol um pequency \\
col pert age
\end{tabular}

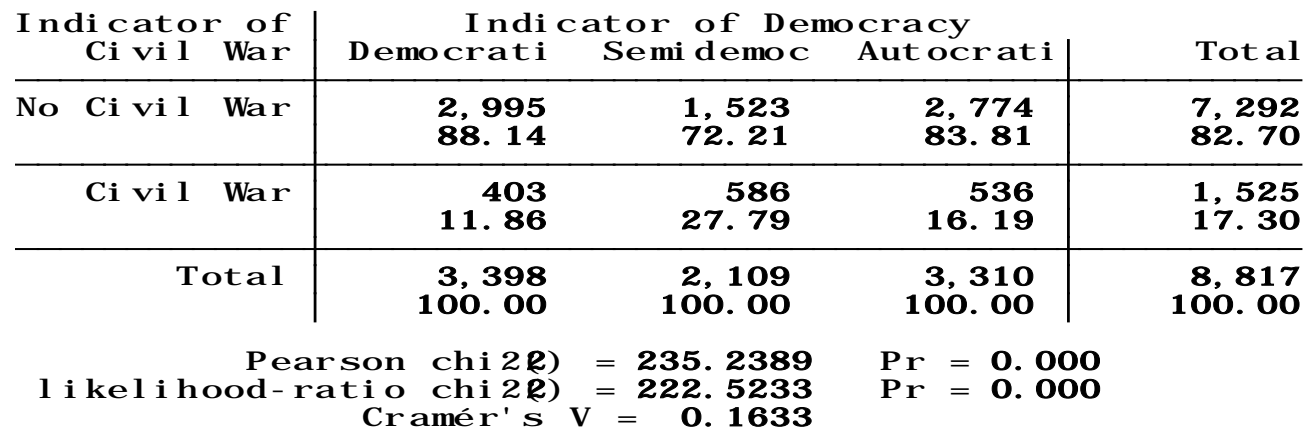

The chi square test of independence indicates that association between regime type and onset of civil war is statistically significant,

$\left[\chi^{2}\right](2, \mathrm{~N}=8817)=235.24,[\mathrm{p}]<0.001$.

Countries with strong democratic or autocratic regime were less likely to experience civil war than those with semi-democratic regimes. The Cramer's $v$ of 0.16 also indicates a possible weak association between regime type and onset of civil war. 


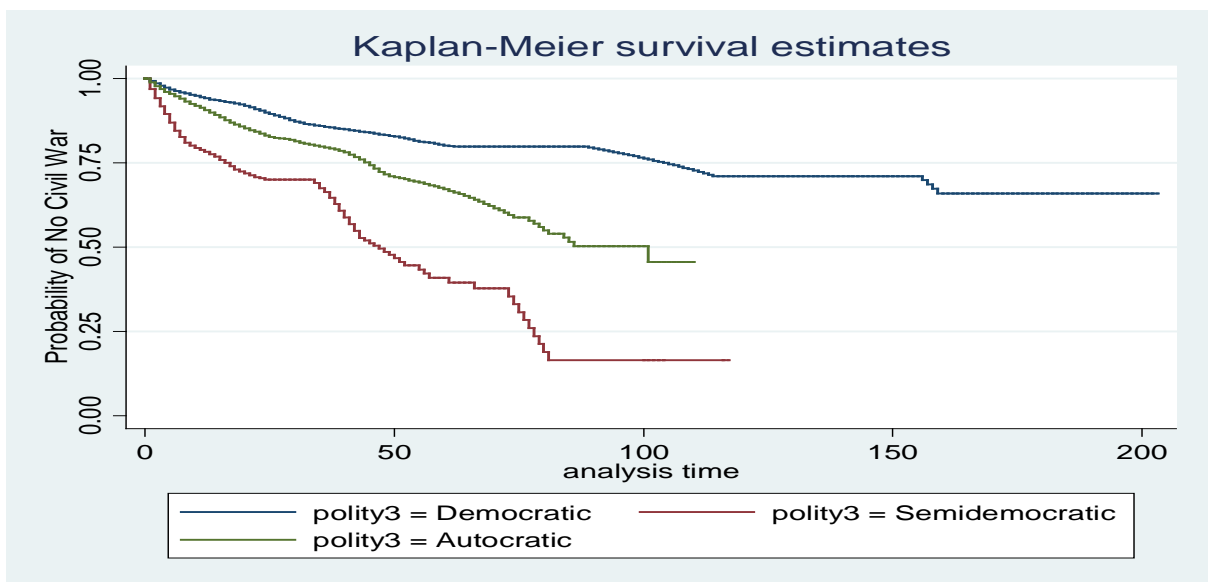

Figure 1: Kaplan-Meier estimates for the three types of regime

From Figure 1, it is noted that democratic and autocratic regimes are less prone to civil war than semi-democratic regime. Moreover, democratic regime is seen to be experiencing the least incidences of civil war. This result is consistent with that observed in Table 1.

\begin{tabular}{|rrrrrr|}
\hline pol i ty3 & D & Y & Rat e & Lower & Upper \\
\hline Democrat i c & 373 & $1.1 e+03$ & 0.35323 & 0.31914 & 0.39096 \\
Sem democrat i c & 342 & 187.8800 & 1.82031 & 1.63726 & 2.02383 \\
Aut ocrat i c & 478 & 654.2100 & 0.73065 & 0.66800 & 0.79918 \\
\hline
\end{tabular}

Table 2: Estimated rates of civil war (per 100 years) and lower/upper bounds of 95\% confidence intervals for the 3 regime types

The rates of civil war (per 100 years) in Table 2 once again confirm that semi-democratic regimes experience greater incidences of civil war than democratic or autocratic regimes.

Table 3: Estimated rate ratio and the corresponding 95\% confidence interval between the 3 regime type.

\begin{tabular}{|c|c|c|c|c|c|c|}
\hline - t & Haz. Ratio & Std. Err. & $z$ & $P>|z|$ & [ $95 \%$ Conf & I nt erval \\
\hline $\begin{aligned} \text { I pol it y3_1 } \\
\text {-I pol it y3__2 }\end{aligned}$ & $\begin{array}{l}\text { 5. } 153285 \\
\text { 2. } 068471\end{array}$ & $\begin{array}{l}.3858067 \\
.1429045\end{array}$ & $\begin{array}{l}21.90 \\
10.52\end{array}$ & $\begin{array}{l}0.000 \\
0.000\end{array}$ & $\begin{array}{l}\text { 4. } 449979 \\
1.806518\end{array}$ & $\begin{array}{l}\text { 5. } 967747 \\
\text { 2. } 368407\end{array}$ \\
\hline$-t$ & Haz. Ratio & Std. Err. & $z$ & $P>|z|$ & [ $95 \%$ Conf & . Interval ] \\
\hline (1) & 2. 491351 & 1764472 & 12.89 & 0.000 & 2. 16845 & 2.862334 \\
\hline
\end{tabular}

Table 3 shows that compared to a democratic regime, a semi-democratic regime and an autocratic regime are 5 and 2 times more likely, respectively, to experience episodes of civil war. Moreover, a semi-democratic regime is about 2.5 times more prone to civil war than an autocratic regime. Each of these rates are significantly different, [p] less than 0.01 in each case. Once again these results are consistent with those found earlier. 


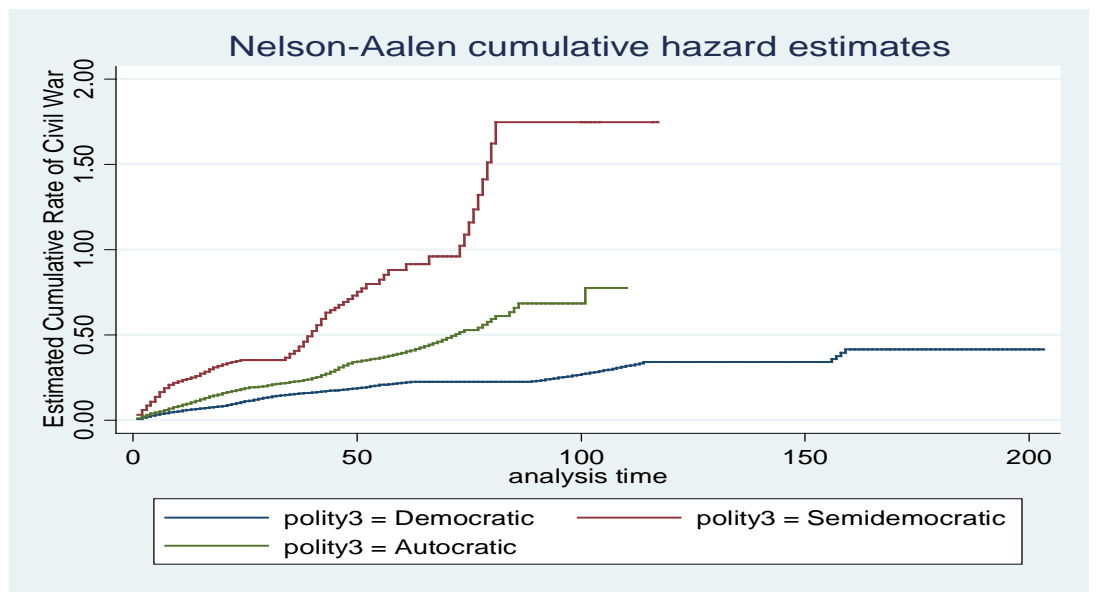

Figure 2: Nelson-Aalen curves for the 3 regimes.

The Nelson-Aalen curves in Figure 2 further affirm the earlier results that semi-democratic regimes are more prone to civil war than democratic or autocratic regimes.

Based on the analysis of the of the data from POLITY IV project (Marshall and Keith 2016), the null hypothesis can be rejected, and the theory is significantly supported.

\section{Implications and conclusions}

The findings of this research may be broadly applied. From a theoretical perspective, the theory contributes to the existing democratic peace theory and extends its application from national to domestic peace. From a practical perspective, the theory suggests that governments promote their level of democratic development in order to maintain domestic peace. However, this research can be falsified. (1) There are some unavoidable confounding variables, such as cultural and economic concerns that may affect results. (2) the data collection and research design were limited by my quantitative knowledge (3) the total words limitation. Despite these flaws, this research may still be useful to those who investigate the relations between institutional change and warfare. Though this research may be immature compared to others, I hope more attention will be paid to this subject in future. Moreover, I will continue researching and finish the research paper.

\section{Reference}

[1] Doyle, Michael W. 1986. Liberalism and World Politics. The American Political Science Review 80 (4): 1151-69.

[2] Kellstedt, Paul M., and Guy D. Whitten. 2013. The Fundamentals of Political Science research. Second ed. Cambridge: Cambridge University Press.

[3] Marshall, G. Monty, Ted R. Gurr, and Keith Jaggers. 2016. Polity IV Project: Political Regime Characteristics and Transitions, 1800-2015: Dataset User's Manual. Available at http://www.systemicpeace.org/inscrdata.html 